\title{
Concentration of dissolved iron in the oxygen minimum zone off San Esteban sill, Gulf of California
}

\section{Concentración de hierro disuelto en la zona del mínimo de oxígeno frente al umbral de San Esteban, golfo de California}

\author{
José Antonio Segovia-Zavala*, Francisco Delgadillo-Hinojosa, Miguel Ángel Huerta-Díaz, Albino \\ Muñoz-Barbosa, Manuel Salvador Galindo-Bect, José Martín Hernández-Ayón, Eunise Vanessa \\ Torres-Delgado
}

Instituto de Investigaciones Oceanológicas, Universidad Autónoma de Baja California, Carretera Tijuana-

Ensenada, No. 3917, Fraccionamiento Playitas, Ensenada 22800, Baja California, México.

*Corresponding author. E-mail: jsegovia@uabc.edu.mx

\begin{abstract}
Dissolved iron $\left(\mathrm{Fe}_{\mathrm{d}}\right)$ concentrations are reported for the Gulf of California oxygen minimum zone (OMZ), which was located in front of San Esteban sill, between Subtropical Subsurface Water (SSW) and Pacific Intermediate Water. Mean $\mathrm{Fe}_{\mathrm{d}}$ concentration in the OMZ was $3.84 \pm 2.48 \mathrm{nM}$, with minimum and maximum values of 1.48 and $10.02 \mathrm{nM}$. These concentrations are higher and are enriched in relation to the Tropical Northeast Pacific Ocean OMZ (0.25-1.2 nM), whose waters enter the gulf through SSW. Sediment resuspension and Fe $\mathrm{d}_{\mathrm{d}} \mathrm{enriched}$ waters cause the observed Fe increase at the stations located near San Esteban sill. On the other hand, the relatively lower Fe $\mathrm{d}_{\mathrm{d}}$ concentrations found at the stations farthest from the sill are the result of denitrification in the suboxic zone.
\end{abstract}

Key words: iron, oxygen minimum zone, denitrification, Gulf of California.

RESUMEN. Se registran concentraciones de hierro disuelto $\left(\mathrm{Fe}_{\mathrm{d}}\right)$ en la zona del mínimo de oxígeno (ZMO) del golfo de California, que se ubicó frente al relieve del umbral de San Esteban y entre el Agua Subsuperficial Subtropical (ASS) y el Agua Intermedia del Pacífico. La concentración promedio de $\mathrm{Fe}_{\mathrm{d}}$ en la ZMO fue de $3.84 \pm 2.48 \mathrm{nM}$, con un valor mínimo de $1.48 \mathrm{nM}$ y un máximo de $10.02 \mathrm{nM}$. Estas concentraciones son mayores y están enriquecidas (8:1) en relación con las de la ZMO del océano Pacífico Nororiental Tropical (0.25-1.2 nM), cuyas aguas ingresan al golfo de California mediante el ASS. La resuspensión de sedimentos y aguas ricas en Fe $\mathrm{d}_{\mathrm{d}}$ provocan el incremento de este metal en las estaciones aledañas al umbral de San Esteban. Por otro lado, los valores relativamente menores son producto de la desnitrificación en la zona subóxica en las estaciones más alejadas del umbral de San Esteban.

Palabras clave: hierro, zona del mínimo de oxígeno, desnitrificación, golfo de California.

\section{INTRODUCTION}

Oxygen minimum zones (OMZ) or suboxic layers are characterized by having oxygen concentrations of $<20 \mu \mathrm{M}$ at intermediate depths (Helly and Levin 2004, Paulmier et al. 2011). The OMZ of the Northeast Pacific Ocean is the most important worldwide (Hendrickx and Serrano 2010). It covers most of the Pacific coast of Mexico, except the northern Gulf of California, and extends to a large part of the adjacent ocean (Helly and Levin 2004).

The Gulf of California OMZ is attributed to high rates of primary productivity (Álvarez-Borrego and Lara-Lara 1991) and consequent high respiration rates (Thunell 1998, Delgadillo-Hinojosa et al. 2006). In the northern part of this interior sea, however, its degree of influence is controlled by intense vertical mixing, which transports oxygen to deep waters and attenuates the $\mathrm{OMZ}$ to the south of the large islands and sills (Delgadillo-Hinojosa et al. 2006). It is thus

\section{INTRODUCCIÓN}

Las zonas del mínimo de oxígeno (ZMO) o capas subóxicas se caracterizan por tener concentraciones de oxígeno $<20 \mu \mathrm{M}$ (Helly y Levin 2004, Paulmier et al. 2011). En particular, la ZMO del océano Pacífico Nororiental es de las más importantes a nivel mundial (Hendrickx y Serrano 2010) y se extiende desde las costas mexicanas hasta gran parte del océano adyacente, salvo el extremo norte del golfo de California (GC) (Helly y Levin 2004).

En el GC, la ZMO es atribuida a las altas tasas de productividad orgánica primaria (Álvarez-Borrego y Lara-Lara 1991) y a las consiguientes altas tasas de respiración (Thunell 1998, Delgadillo-Hinojosa et al. 2006). Sin embargo, el grado de influencia de la ZMO hacia el norte de este mar interior es controlada por la mezcla vertical intensa, la cual transporta oxígeno hacia las aguas profundas y atenúa la ZMO al sur de la región de las islas y los umbrales 
suggested that this OMZ is the result of the balance between the intrusion of oxygen-poor water from the East Pacific Ocean, the input of organic matter, its respiration, and the ventilation process due to vertical mixing. The latter is very important for the study of essential trace elements such as Fe, which is affected by redox processes in suboxic areas of the OMZ.

Insoluble oxidative forms of $\mathrm{Fe}(\mathrm{III})$ from oxygenated surface waters are reduced to $\mathrm{Fe}(\mathrm{II})$ under redox conditions (Landing and Bruland 1987, Laës et al. 2006, Alkan and Tüfekçi 2009). These soluble forms increase the concentration of dissolved $\mathrm{Fe}\left(\mathrm{Fe}_{\mathrm{d}}\right)$ and are essential nutrients for photosynthesis (Street and Paytan 2004). There is, however, no biogeochemical information on $\mathrm{Fe}_{\mathrm{d}}$ under dynamic suboxic transition condition, such as those found in the Gulf of California OMZ. This study thus aimed to examine the concentration and distribution of $\mathrm{Fe}_{\mathrm{d}}$ in order to contribute to the construction of its biogeochemical cycle in the central Gulf of California, at the boundary of the OMZ. Our findings are compared with those reported for other suboxic regions of the ocean to obtain a general idea of the distribution of this essential element.

\section{MATERIALS AND METHODS}

Two oceanographic cruises were conducted in the Gulf of California aboard the R/V Francisco de Ulloa, the first in spring 2003 (12-17 May) during spring tides and the second in late summer 2004 (1-10 September) during neap tides. Figure 1 shows the location of the transect along the central axis and between the islands of the central gulf (stations 3, $14,11,24,28,34$, and 38). Only four hydrographic stations $(24,28,34$, and 38) were considered to study the OMZ because its boundary was located off San Esteban sill (SES). All the methodology (sample collection, analysis of metals and hydrochemical variables) is described in Segovia-Zavala et al. $(2009,2010)$. Water samples were collected at 10, 20, $50,75,100,200$, and $500 \mathrm{~m}$ depth.

\section{Measurement of Fe in dissolved phase}

The dissolved phase of Fe was analyzed, defined as all the material passing through a $0.45-\mu \mathrm{m}$ filter, and only total $\mathrm{Fe}_{\mathrm{d}}$ was recorded. Hence, $\mathrm{Fe}(\mathrm{II})$ and $\mathrm{Fe}(\mathrm{III})$ species are not reported. $\mathrm{Fe}_{\mathrm{d}}$ was evaluated by extraction and preconcentration with organic chelates (APDC). Fe was determined by high-resolution inductively-coupled plasma mass spectrometry. The detection limit was $0.036 \mathrm{nM}$.

\section{RESULTS}

The mean concentration of $\mathrm{Fe}_{\mathrm{d}}$ for both surveys in the $\mathrm{OMZ}$ was $3.84 \pm 2.48 \mathrm{nM}$, with minimum and maximum values of 1.48 and $10.02 \mathrm{nM}$, respectively. The minimum value was recorded in spring at $400 \mathrm{~m}$ depth (station 28) and
(Delgadillo-Hinojosa et al. 2006). Por lo tanto, se sugiere que la ZMO en el GC es producto del balance entre la intrusión de aguas pobres en oxígeno del océano Pacífico Este, el aporte de material orgánico, su respiración y el proceso de ventilación por la mezcla vertical. Lo anterior, es muy importante para el estudio de elementos traza esenciales como el $\mathrm{Fe}$, el cual es afectado por procesos redox en las áreas subóxicas de la ZMO.

Se ha documentado que las formas oxidadas insolubles de $\mathrm{Fe}(\mathrm{III})$ que provienen de las aguas superficiales oxigenadas, bajo condiciones redox, son reducidas a Fe(II) (Landing y Bruland 1987, Laës et al. 2006, Alkan y Tüfekçi 2009). Estas formas solubles incrementan la concentración de Fe disuelto $\left(\mathrm{Fe}_{\mathrm{d}}\right)$ y son nutrientes indispensables para la fotosíntesis (Street y Paytan 2004). Sin embargo, la información biogeoquímica del $\mathrm{Fe}_{\mathrm{d}}$ en condiciones dinámicas de transición subóxicas, como las encontradas en la ZMO del $\mathrm{GC}$, es nula. Por lo tanto, el presente trabajo se orienta a conocer la concentración y distribución del $\mathrm{Fe}_{\mathrm{d}}$ para contribuir a la construcción del ciclo biogeoquímico $\mathrm{Fe}$ de la porción central del GC, donde tiene su límite la ZMO. Además, se comparan los resultados del presente estudio con los encontrados en otras regiones subóxicas del océano Pacífico para tener una idea general de la distribución de este elemento esencial.

\section{MATERIALES Y MÉTODOS}

Se realizaron dos cruceros oceanográficos en el GC a bordo del B/O Francisco de Ulloa: el primero durante mareas vivas de la primavera de 2003 (12-17 de mayo) y el segundo durante mareas muertas del verano tardío de 2004 (1-10 de septiembre). En la figura 1 se muestra el transecto ubicado a lo largo del eje central y entre las islas del GC (estaciones 3, 14, 11, 24, 28, 34 y 38; fig. 1). Para el estudio de la ZMO, solamente se consideraron cuatro estaciones hidrográficas $(24,28,34$ y 38$)$ debido a que la frontera de la ZMO se localizó frente al umbral de San Esteban (USE). Toda la metodología de la recolección de muestras y de los análisis de metales y variables hidroquímicas está documentada en Segovia-Zavala et al. 2009, 2010. Las muestras de agua se recolectaron a $10,20,50,75,100,200$ y $500 \mathrm{~m}$ de profundidad.

\section{Medición del metal en la fase disuelta}

Se analizó la fase disuelta de $\mathrm{Fe}$, que se definió como todo el material que pasa a través de un filtro con tamaño de poro de $0.45 \mu \mathrm{m}$, y solo se registró el $\mathrm{Fe}_{\mathrm{d}}$ total. Las especies $\mathrm{Fe}$ (II) y Fe (III) no se registraron. El $\mathrm{Fe}_{\mathrm{d}}$ se evaluó por extracción orgánica y preconcentración con quelantes orgánicos (APDC). El Fe se determinó por espectrometría de masas de alta resolución con plasma acoplado por inducción. El límite de detección fue de $0.036 \mathrm{nM}$. 


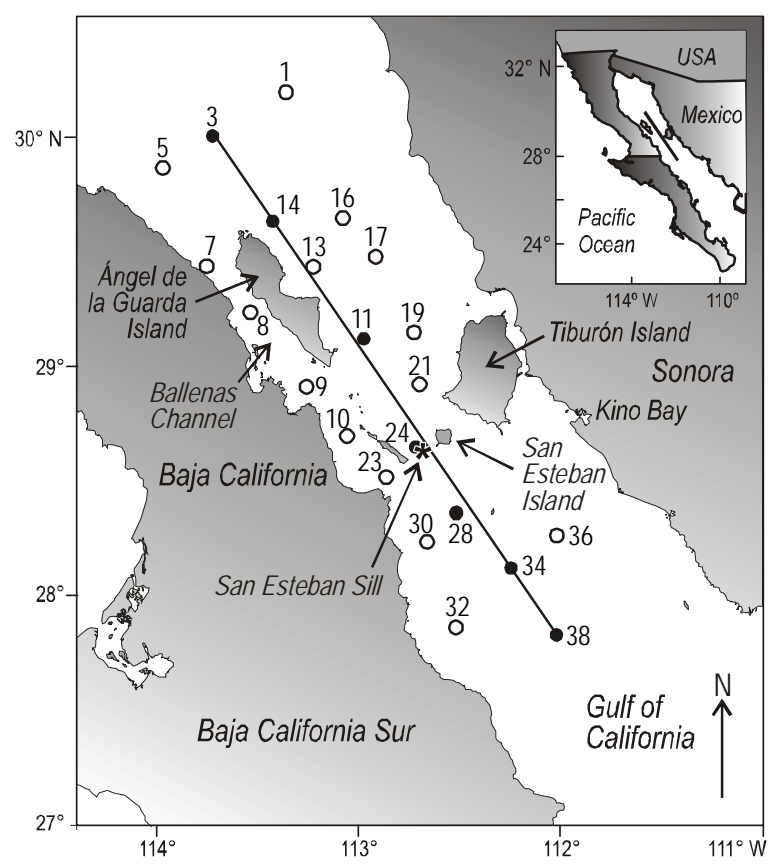

Figure 1. Distribution of the sampling stations (numbers) in the Gulf of California. Metal samples were collected at the stations indicated with a black circle $(3,14,11,24,28,34$, and 38). Stations $24,28,34$, and 38 were used to study the oxygen minimum zone.

Figura 1. Distribución de las estaciones de muestreo (números) en el golfo de California. En las estaciones marcadas con círculos negros $(3,14,11,24,28,34$ y 38$)$ se recolectaron las muestras de metal. Las estaciones 24, 28, 34 y 38 fueron las utilizadas para estudiar la zona del mínimo de oxígeno (ZMO).

the maximum value in summer at $600 \mathrm{~m}$ depth (station 28). Mean $\mathrm{Fe}_{\mathrm{d}}$ concentration for spring and summer was $3.55 \pm$ 1.57 and $4.03 \pm 3.66 \mathrm{nM}$, respectively.

The vertical $\mathrm{Fe}_{\mathrm{d}}$ profiles for stations 24, 28, 34, and 38, where the OMZ occurs between 300 and $600 \mathrm{~m}$ depth, are shown in figure 2(a,b). The OMZ was located between Subtropical Subsurface Water (SSW) and Pacific Intermediate Water (PIW). The plots show similar distributions for both sampling periods. In general, in the $\mathrm{OMZ}, \mathrm{Fe}_{\mathrm{d}}$ concentrations increase with depth and this becomes more evident near SES; however, this is not exclusive to the suboxic zone. High concentrations were also detected in spring (5.1 and $12.3 \mathrm{nM}$ at 300 and $400 \mathrm{~m}$, respectively) at the station (24) closest to SES outside the OMZ.

\section{DISCUSSION}

The mean concentration of $\mathrm{Fe}_{\mathrm{d}}$ in the $\mathrm{OMZ}$ for both surveys was high $(3.84 \pm 2.48 \mathrm{nM})$, because the minimum concentration recorded in this study (1.48 nM in SSW; fig. 2a) is relatively higher than the highest concentration $(1.20 \mathrm{nM})$ recorded in the nucleus of the OMZ of the Northeast Pacific Ocean, off Manzanillo, Mexico (Hopkinson and

\section{RESUltados}

La concentración promedio del $\mathrm{Fe}_{\mathrm{d}}$ para ambos muestreos en la ZMO fue de $3.84 \pm 2.48 \mathrm{nM}$, con un valor mínimo de $1.48 \mathrm{nM}$ y máximo de $10.02 \mathrm{nM}$. El valor mínimo se registró en primavera a los $400 \mathrm{~m}$ de profundidad (estación 28) y el valor máximo, en verano a los $600 \mathrm{~m}$ (estación 28). La concentración promedio de $\mathrm{Fe}_{\mathrm{d}}$ para primavera y verano fue $3.55 \pm 1.57$ y $4.03 \pm 3.66 \mathrm{nM}$, respectivamente.

En las figura 2(a,b) se presentan los perfiles verticales de $\mathrm{Fe}_{\mathrm{d}}$ para las estaciones 24, 28, 34 y 38, donde se ubicó la ZMO entre los 300 a $600 \mathrm{~m}$ de profundidad. La ZMO se ubicó entre el Agua Subsuperficial Subtropical (ASS) y el Agua Intermedia del Pacífico. En las gráficas se observó que en ambos periodos de muestreo los perfiles tuvieron distribuciones similares. En general, en la ZMO, las concentraciones de $\mathrm{Fe}_{\mathrm{d}}$ se incrementaron con la profundidad y esto fue más evidente hacia el USE. Sin embargo, esto último no fue exclusivo de la zona subóxica; en primavera también se detectaron altas concentraciones $(5.1$ y $12.3 \mathrm{nM}$ a 300 y $400 \mathrm{~m}$, respectivamente) en la estación (24) más próxima al USE, fuera de la ZMO.

\section{Discusión}

La concentración promedio del $\mathrm{Fe}_{\mathrm{d}}$ en la ZMO para ambos muestreos fue alta $(3.84 \pm 2.48 \mathrm{nM})$ debido a que la concentración mínima (1.48 $\mathrm{nM}$ en el ASS, fig. 2a) fue relativamente mayor que la concentración más alta $(1.20 \mathrm{nM})$ registrada en el núcleo de la ZMO del océano Pacífico Nororiental, frente a Manzanillo, México (Hopkinson y Barbeau 2007). Este núcleo se sitúa en el ASS, la cual ingresa al GC (Delgadillo-Hinojosa et al. 2006). Los valores registrados en el presente estudio son similares a las concentraciones (2.3-3.8 nM) registradas para el núcleo del agua subóxica de la zona de surgencia del Perú (Bruland et al. 2005); no obstante, son relativamente menores que las registradas en las condiciones hipóxicas de las aguas sobre la plataforma de Oregón $(21.5 \pm 2.1 \mathrm{nM}$, Lohan y Bruland 2008) y de la zona subóxica anexa a los sedimentos del Perú (10-50 nM, Bruland et al. 2005). En este estudio, el valor máximo del $\mathrm{Fe}_{\mathrm{d}}$ en la ZMO durante el verano fue de $10.02 \mathrm{nM}$ y se encontró asociado a una concentración de oxígeno de $15 \mu \mathrm{M}$ (fig. 2b). Sin embargo, los valores altos $(5.1$ y $12.3 \mathrm{nM})$ encontrados fuera de la ZMO (estación 24) durante la primavera y asociados a concentraciones de oxígeno mayores ( 47 y $32 \mu \mathrm{M})$ pueden ser consecuencia de la resuspensión de sedimentos. Estos resultados, en relación con la ZMO del Pacífico Noroeriental (Hopkinson y Barbeau 2007), plantean una consistencia y un patrón general de la concentración y distribución de este elemento esencial en la zona subóxica del GC; sin embargo, en relación con el núcleo de la ZMO del ASS (Hopkinson y Barbeau 2007) que ingresa al GC, sugieren que las concentraciones de Fe en la ZMO del GC están enriquecidos (entre 

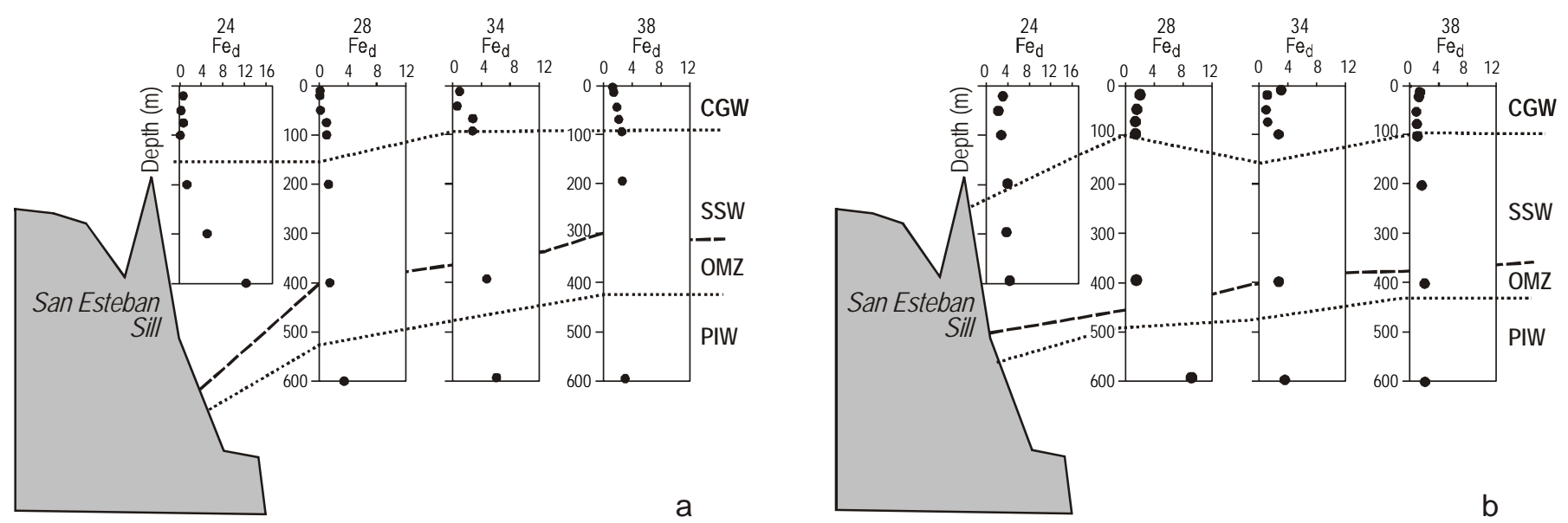

Figure 2. Profiles of dissolved $\mathrm{Fe}\left(\mathrm{Fe}_{\mathrm{d}}, \mathrm{nM}\right)$ in the oxygen minimum zone (OMZ) of the central Gulf of California in (a) spring 2003 and (b) summer 2004. Numbers on top correspond to the sampling stations (see fig. 1). The dashed line delimits the OMZ and the dotted lines the water masses: Gulf of California Water (GCW), Subtropical Subsurface Water (SSW), and Pacific Intermediate Water (PIW).

Figura 2. Perfiles de Fe disuelto $\left(\mathrm{Fe}_{\mathrm{d}}, \mathrm{nM}\right)$ en la zona del mínimo de oxígeno (OMZ) en la región central del golfo de California en (a) la primavera de 2003 y (b) el verano de 2004. Los números en la parte superior indican las estaciones de muestreo (ver fig. 1). La línea de trazo corto delimita la ZMO y la línea punteada delimita las masas de agua: Agua del Golfo de California (GCW), Agua Subsuperficial Subtropical (SSW) y Agua Intermedia del Pacifico (PIW).

Barbeau 2007). This nucleus occurs in SSW, which enters the Gulf of California (Delgadillo-Hinojosa et al. 2006). Our values are similar to the concentrations $(2.3-3.8 \mathrm{nM})$ reported for the nucleus of suboxic water in the upwelling zone off Peru (Bruland et al. 2005); however, they are relatively lower than those obtained for hypoxic Oregon shelf waters $(21.5 \pm$ $2.1 \mathrm{nM}$, Lohan and Bruland 2008) and in the suboxic zone of sediments off Peru (10-50 nM, Bruland et al. 2005). In the present study, the maximum $\mathrm{Fe}_{\mathrm{d}}$ value in the $\mathrm{OMZ}$ during summer was $10.02 \mathrm{nM}$ and it was associated with an oxygen concentration of $15 \mu \mathrm{M}$ (fig. $2 b$ ). The high values (5.1 and $12.3 \mathrm{nM}$ ) recorded outside the OMZ (station 24) during the May spring tides, and associated with higher oxygen concentrations ( 47 and $32 \mu \mathrm{M}$ ), may be the result of sediment resuspension. These results in relation to the Northeast Pacific OMZ (Hopkinson y Barbeau 2007) indicate a consistency and general pattern of the concentration and distribution of this essential element in the suboxic zone of the Gulf of California; however, in relation to the OMZ nucleus in SSW (Hopkinson and Barbeau 2007) that enters the Gulf of California, they suggest that the Fe concentrations in the gulf OMZ are enriched (between two and eight times), so other internal processes must be increasing the levels of $\mathrm{Fe}_{\mathrm{d}}$.

The proximity of the OMZ allows the resuspension of Ferich sediments (fig. 3a, b), as indicated by the high $\mathrm{Fe}_{\mathrm{d}}$ values obtained at station 24 (outside the OMZ) and at stations 28 and 34 (within the OMZ; fig. 2a, b). This suggests that in addition to the low oxygen levels, the increase in $\mathrm{Fe}_{\mathrm{d}}$ may also be due to the influence of transport of water associated with vertical mixing at the stations close to SES (fig. 3a, b). Delgadillo-Hinojosa et al. (2006) reported that to the south of the Midriff Islands the subsurface maximum values of dos y ocho veces más), por lo que deben existir procesos internos que incrementen los niveles de $\mathrm{Fe}_{\mathrm{d}}$.

La proximidad de la ZMO con el USE permite la elevación y resuspensión de sedimentos ricos en hierro (fig. 3a y b). Lo anterior, se puede observar de los valores altos de $\mathrm{Fe}_{\mathrm{d}}$ encontrados en la estación 24 (fuera de la ZMO) y en las estaciones 28 y 34 (dentro de la ZMO; fig. $2 \mathrm{a}$, b). Esto sugiere que además de los bajos niveles de oxígeno, los incrementos de $\mathrm{Fe}_{\mathrm{d}}$ también podrían deberse a la influencia del fondo y a la elevación del nivel de agua por mezcla vertical en las estaciones próximas al USE (fig. 3a y b). Delgadillo-Hinojosa et al. (2006) registraron que, al sur de la región de las islas grandes del GC, los máximos subsuperficiales de Mn disuelto parecen estar influenciados por la resuspensión de sedimentos a la ZMO a lo largo del margen continental (USE). También, se ha documentado que las mareas vivas en la zona de los umbrales producen una mezcla vertical de la columna de agua que llega más allá de los $500 \mathrm{~m}$ de profundidad (Simpson et al. 1994), lo que podría resuspender sedimentos hacia la ZMO que se ubicó frente al USE entre los $400 \mathrm{a} 600 \mathrm{~m}$ de profundidad (fig. 3a y b). Lejos de la zona de resuspensión del USE, los incrementos de la concentración de $\mathrm{Fe}_{\mathrm{d}}$ podrían ser producto de la desnitrificación en la zona suboxica.

Se ha registrado que en la ZMO se lleva a cabo la desnitrificación e incremento del $\mathrm{Fe}_{\mathrm{d}}$ (Bruland 2006). En la ZMO, en el $\mathrm{GC}$, el $\mathrm{Fe}_{\mathrm{d}}$ se asoció negativamente con el oxígeno disuelto (fig. 4), lo que indica que el $\mathrm{Fe}_{\mathrm{d}}$ se incrementa conforme el oxígeno disminuye por debajo de $20 \mu \mathrm{M}$. Lo anterior sugiere que, debido a que también son utilizadas como aceptores de electrones para oxidar la materia orgánica 


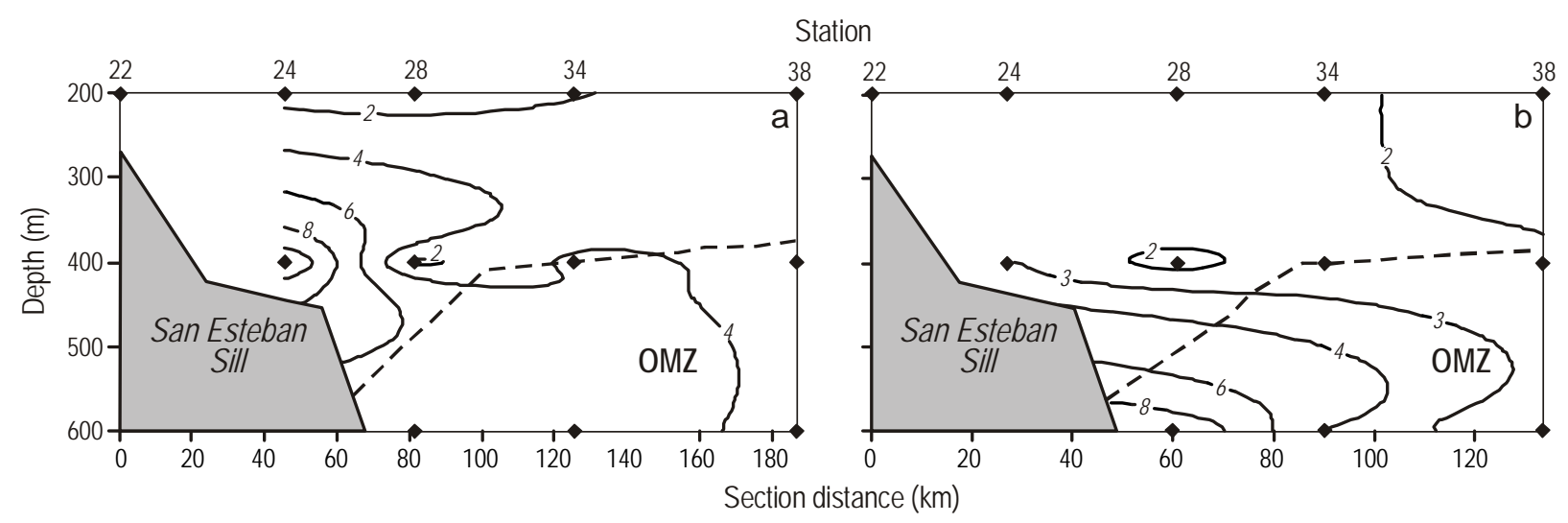

Figure 3. Vertical distribution of dissolved Fe (nM, isolines) in the oxygen minimum zone (OMZ) of the central Gulf of California in (a) spring 2003 and (b) summer 2004. Black dots indicate the depth levels where the samples were collected. The dashed line indicates a concentration of $20 \mu \mathrm{M} \mathrm{O}_{2}$, which is the upper limit of the OMZ.

Figura 3. Distribución vertical del Fe disuelto (nM, isolíneas) en la zona del mínimo de oxígeno (OMZ) en la región central del golfo de California en (a) la primavera de 2003 y (b) el verano de 2004. Los puntos negros indican los niveles de profundidad a los cuales se recolectaron las muestras. La línea punteada indica la concentración de $20 \mu \mathrm{M}$ de $\mathrm{O}_{2}$, que es el límite superior de la ZMO.

dissolved $\mathrm{Mn}$ are influenced by the resuspension of sediments to the OMZ along the continental margin (SES). Moreover, spring tides in the sills region have been reported to produce vertical mixing in the water column down to more than $500 \mathrm{~m}$ depth (Simpson et al. 1994), which could resuspend sediments to the OMZ located between 400 and $600 \mathrm{~m}$ depth off SES (fig. 3a, b). Far from the resuspension area of the sill, the increase in $\mathrm{Fe}_{\mathrm{d}}$ concentrations may be the result of denitrification in the suboxic zone.

Denitrification and an increase in $\mathrm{Fe}_{\mathrm{d}}$ occur in $\mathrm{OMZ}$ (Bruland 2006). In the Gulf of California $\mathrm{OMZ}, \mathrm{Fe}_{\mathrm{d}}$ was negatively related to dissolved oxygen (fig. 4), indicating that $\mathrm{Fe}_{\mathrm{d}}$ increases as oxygen decreases to below $20 \mu \mathrm{M}$. As the insoluble oxidative forms of $\mathrm{Fe}$ (III) and Mn(IV) from surface waters are also used as electron acceptors to oxidize organic matter (Bruland 2006, Moffett et al. 2007), under denitrifying conditions they are reduced to soluble $\mathrm{Fe}(\mathrm{II})$ and $\mathrm{Mn}(\mathrm{II})$. However, the relation between $\mathrm{Fe}_{\mathrm{d}}$ and dissolved oxygen presents scattered data (fig. 4) that produce a low correlation coefficient $(R=0.40)$, suggesting that in addition to the low oxygen levels, other processes are influencing the concentration and distribution of $\mathrm{Fe}_{\mathrm{d}}$ in the OMZ. Sediment resuspension may be a factor influencing $\mathrm{Fe}_{\mathrm{d}}$ concentrations in waters close to SES (fig. $3 \mathrm{a}, \mathrm{b}$ ), since in both sampling periods the highest concentrations occurred adjacent to the sill. On the other hand, the lowest $\mathrm{Fe}_{\mathrm{d}}$ values found at the station farthest from SES (38) could be attributed to denitrification. According to Hopkinson and Barbeau (2007), the redox state of $\mathrm{Fe}$ and its species is affected by suboxic conditions. In this study, however, there were no conditions for Fe to be fully reduced to $\mathrm{Fe}(\mathrm{II})$ and neither was there a considerable accumulation of $\mathrm{Fe}_{\mathrm{d}}$ in the suboxic zone. Consequently, the dispersion of the data in figure 4 suggests that the processes
(Bruland 2006, Moffett et al. 2007), las formas oxidadas insolubles de $\mathrm{Fe}(\mathrm{III})$ y $\mathrm{Mn}(\mathrm{IV})$, que provienen de las aguas superficiales, son reducidas a las formas solubles $\mathrm{Fe}(\mathrm{II})$ y $\mathrm{Mn}$ (II) bajo condiciones desnitrificantes. Sin embargo, la relación entre la $\mathrm{Fe}_{\mathrm{d}}$ y el oxígeno disuelto presenta datos dispersos (fig. 4) que producen un coeficiente de correlación bajo $(R=0.40)$, lo que sugiere que, además de los niveles bajos de oxígeno, existen otros procesos que están influenciando la concentración y distribución de $\mathrm{Fe}_{\mathrm{d}}$ en la ZMO. Es posible que la resuspensión de sedimentos sea un factor que esté influenciando la concentración de $\mathrm{Fe}_{\mathrm{d}}$ en las aguas cercanas al USE (fig. $3 \mathrm{a}, \mathrm{b}$ ), ya que en ambos periodos de muestreo las concentraciones más altas se presentaron adyacentes a dicho umbral. Por otro lado, los valores más bajos de $\mathrm{Fe}_{\mathrm{d}}$ encontrados en la estación más alejada del USE (38) podrían ser atribuidos a la desnitrificación. De acuerdo con Hopkinson y Barbeau (2007), el estado redox y la especiación del Fe son afectados por las condiciones subóxicas. Sin embargo, en este estudio, no se presentaron las condiciones para que el Fe fuese reducido totalmente a Fe (II), así como tampoco hubo acumulación considerable de $\mathrm{Fe}_{\mathrm{d}}$ en la zona subóxica. En consecuencia, la dispersión de los datos en la figura 4 sugiere que los procesos que afectan la concentración de $\mathrm{Fe}_{\mathrm{d}}$ en la ZMO, en las estaciones cercanas al USE, podrían ser una mezcla de condiciones reductoras y resuspensión de sedimentos, acentuándose esto último en primavera, cuando la columna de agua es menos estable y las mareas vivas en combinación con el umbral producen una mezcla más efectiva. Por otro lado, en las estaciones más lejanas al USE, el factor predominante podría ser el efecto de las condiciones reductoras. Todo indica que los procesos que controlan la concentración y distribución del Fe en la ZMO cercana al USE son muy complejos y podrían ser muy variados, por 
affecting $\mathrm{Fe}_{\mathrm{d}}$ concentrations in the $\mathrm{OMZ}$, at the stations close to SES, may be a combination of reducing conditions and sediment resuspension, the latter being more prominent in spring when the water column is less stable and spring tides together with the sill produce a more effective mixing. At the stations farthest from SES, the predominant factor could be the effect of the reducing conditions. It is apparent that the processes controlling the concentration and distribution of $\mathrm{Fe}$ in the OMZ close to SES are very complex and likely varied, and further studies are needed to better define its distribution and biogeochemistry in this dynamic interior sea and especially in SES.

\section{ACKNOWLEDGMENTS}

This study was supported by the National Council for Science and Technology (CONACYT, Mexico, SEP-2004C01-46576) and the Autonomous University of Baja California (UABC internal project 565). We thank the anonymous reviewers for their valuable comments and suggestions.

English translation by Christine Harris.

\section{REFERENCES}

Alkan N, Tüfekçi M. 2009. Distributions of dissolved forms of manganese and iron in the water column of the southeastern Black Sea. Turkish J. Fish. Aquat. Sci. 9: 159-164. http://dx.doi.org/10.4194/trjfas.2009.0206

Álvarez-Borrego S, Lara-Lara R. 1991. The physical environment and primary productivity of the Gulf of California. In: Dauphin JP, Simoneit BR (eds.), The Gulf Pennisular Province of the Californias. AAPG Mem. 47: 555-567.

Bruland KW. 2006. A review of the chemistries of redox sensitive elements within suboxic zones of the oxygen minimum regions. Suplemento Gayana 70: 6-13. http://dx.doi.org/10.4067/S0717-65382006000300003

Bruland KW, Rue EL, Smith GJ, DiTullio GR. 2005. Iron, macronutrients and diatom blooms in the Peru upwelling regime: Brown and blue waters of Peru. Mar. Chem. 93: 81- 103. http://dx.doi.org/10.1016/j.marchem.2004.06.011

Delgadillo-Hinojosa F, Segovia-Zavala JA, Huerta-Díaz MA, Atilano-Silva H. 2006. Influence of geochemical and physical processes on the vertical distribution of manganese in Gulf of California waters. Deep-Sea Res. I 53: 1301-1319. http://dx.doi.org/10.1016/j.dsr.2006.06.002

Hendrickx ME, Serrano D. 2010. Impacto de la zona de mínimo de oxígeno sobre los corredores pesqueros en el Pacífico mexicano. Interciencia 35: 12-18.

Helly JJ, Levin LA. 2004. Global distribution of naturally occurring marine hypoxia on continental margins. Deep-Sea Res. I 51: $1159-1168$ http://dx.doi.org/10.1016/j.dsr.2004.03.009

Hopkinson BM, Barbeau KA. 2007. Organic and redox speciation of iron in the eastern tropical North Pacific suboxic zone. Mar. Chem. 106: 2-17.

http://dx.doi.org/10.1016/j.marchem.2006.02.008

Laës A, Blain S, Laan P, Ussher SJ, Achterberg EP, Tréguer P, de Baars HJW. 2006.

http://dx.doi.org/10.5194/bg-4-181-2007

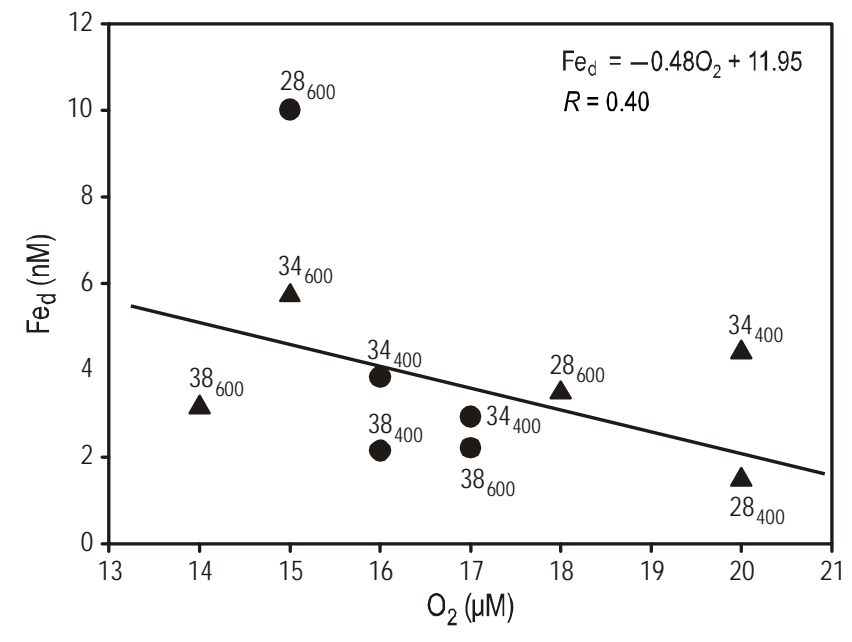

Figure 4. Dissolved $\mathrm{Fe} v s \mathrm{O}_{2}$ in spring $(\boldsymbol{\Delta})$ and summer $(\bullet)$ in the oxygen minimum zone at stations 28,34 , and 38 . The station number and depth (subscripts) are indicated.

Figura 4. Relación Fe disuelto vs $\mathrm{O}_{2}$ en primavera ( $\boldsymbol{\Delta}$ ) y verano (•) en la zona del mínimo de oxígeno de las estaciones 28, 34 y 38. Se denotan las estaciones y la profundidad (subíndices).

lo que deberán realizarse más estudios que ayuden a definir de una mejor manera su distribución y biogeoquímica en este mar interior tan dinámico como es el GC y sobre todo en la región del USE.

\section{Agradecimientos}

Este estudio fue financiado por el Consejo Nacional de Ciencia y Tecnología (CONACYT, SEP-2004-C01-46576) y por la Universidad Autónoma de Baja California (UABC, proyecto interno no. 565). Se agradece a los revisores anónimos que, con sus comentarios y sugerencias, enriquecieron este trabajo.

Landing WM, Bruland KW. 1987. Contrasting biogeochemistry of iron and manganese in the Pacific Ocean. Geochim. Cosmochim. Acta 51: 29-43. http://dx.doi.org/10.1016/0016-7037(87)90004-4

Lohan MC, Bruland KW. 2008. Elevated Fe (II) and dissolved Fe in hypoxic shelf waters off Oregon and Washington: An enhanced source of iron to coastal upwelling regimes. Environ. Sci. Technol. 42: 6462-6468. http://dx.doi.org/10.1021/es800144j

Moffett JW, Goepfort TJ, Naqvi SWA. 2007. Reduced iron associated with secondary nitrite maxima in the Arabian Sea. Deep-Sea Res. I 54: 1341-1349. http://dx.doi.org/10.1016/j.dsr.2007.04.004

Paulmier A, Ruiz-Pino D, Garçon V. 2011. $\mathrm{CO}_{2}$ maximum in the oxygen minimum zone (OMZ). Biogeosciences 8: 239-252. http://dx.doi.org/10.5194/bg-8-239-2011

Segovia-Zavala JA, Delgadillo-Hinojosa F, Lares-Reyes ML, Huerta-Díaz MA, Muñoz-Barbosa A, Torres-Delgado EV. 2009. Atmospheric input and concentration of dissolved iron in the surface layer of the Gulf of California. Cienc. Mar. 35: 75-90. 
Segovia-Zavala JA, Lares-Reyes ML, Delgadillo-Hinojosa F, TovarSánchez A, Sañudo-Wilhelmy SA. 2010. Dissolved iron distributions in the central region of the Gulf of California. Deep-Sea Res. I: 53-64. http://dx.doi.org/10.1016/j.dsr.2009.10.007

Simpson JH, Souza AJ, Lavín MF. 1994. Tidal mixing in the Gulf of California. In: Beven JK, Chatwin PC, Millbank JH (eds.), Mixing and Transport in the Environment. John Wiley, London, pp. $169-182$.
Street JH, Paytan A. 2004. Iron, phytoplankton growth, and the carbon cycle. In: Sigel A, Sigel H, Sigel RKO (eds.), Metal Ions in Biological Systems. Vol. 43 Biogeochemical Cycles of the Elements. Marcel Dekker, New York, pp. 153-193.

Thunell RC. 1998. Seasonal and annual variability in particle fluxes in the Gulf of California: A response to climate change. DeepSea Res. I: 2059-2083.|

http://dx.doi.org/10.1016/S0967-0637(98)00053-3

Received August 2012,

received in revised form April 2013, accepted May 2013. 